\section{OPEN ACCESS JOURNAL PUBLISHING AND AMICUS CURIAE}

Amicus Curiae has been at the centre of an exciting and innovative on-line publishing project conducted with the School of Advanced Study (SAS) of the University of London which will help to promote both new and established journals by making them accessible to a much wider readership than they could hope to attain through print publication alone.

The School, as many readers will know, is composed of 10 specialist research institutes, one of which is the Institute of Advanced Legal Studies. The role of SAS is to promote and facilitate research, which it seeks to achieve through initiatives which include programmes of conferences and seminars, the provision of specialist library facilities, and publishing projects which utilise both traditional print processes and developing electronic technologies.

In May this year SAS obtained funding to develop a system of open access journal publishing. The support came from JISC, a body which helps UK educational organisations to develop information and digital systems. The new system is based on SAS-Space, the institutional repository for the School, which makes research available from across the member institutes.

Amicus Curiae has been used as a test case and model for the JISC project, the central purpose of which is to produce an electronic infrastructure capable of creating new on-line journals, or displaying existing titles such as Amicus, to make them readily available to a wider audience. Amicus is now available on-line from issue 46 (2003) to the current issue, and work will continue over the coming months to add issues 1-45. In addition, a feasibility study using Amicus has been conducted into the adoption of an electronic system to manage the workflow of manuscripts for the journal. It should be stressed that for the foreseeable future Amicus will be maintaining both a print and web-based presence.

The infrastructure created by the JISC project offers a new collaborative and low-cost journal publishing model for the School's member institutes in partnership with learned societies and other associated bodies. This will provide an opportunity for an institute or other body which cannot afford the production and distribution costs associated with a traditional periodical to launch an electronic publication in return for a small start-up fee. Open access will offer new opportunities to unlock past work, research and engage with a wider audience (including young academics and their students), deliver new research tools, include social networking tools to offer further dialogue on current legal topics, and offer public access to socio-legal commentary.

\section{Articles}

The applicable law in the Caribbean Single Market 2 Constitutional developments since the Lisbon Treaty in the area of freedom, security and justice at supranational and national level

Institute News

\section{Articles (cont'd)}

Constitutional jurisprudence

Terrorism litigation as deterrence under international law - from protecting human rights to countering hybrid threats

The spread of international arbitration: a survey based on views expressed in leading textbooks

Employee participation under German law

A launch event for the SAS Open Access Journals project organised by Dr Peter Webster, SAS-Space Repository Manager, was held at Senate House on October 20. Peter introduced the SAS Open Journals system and Dr Damien Short, of the Institute of Commonwealth Studies, spoke on the issues facing those wishing to launch a new journal. Steve Whittle, IALS Information Systems Manager, spoke on the technical challenges involved in moving Amicus Curiae from print to web, and I provided an editorial perspective. The seminar concluded with delegates and speakers splitting into group sessions to discuss issues of common interest.

A great deal of time has been devoted to the open access journals project by Peter, Steve and the University of London Computer Centre, and I am very grateful for all the work they have put in to open new horizons for Amicus. Those wishing to access Amicus Curiae can do so at http://journals.sas.ac.uk/amicus.

\section{Julian Harris}

Deputy General Editor, Amicus Curiae Associate Research Fellow, IALS

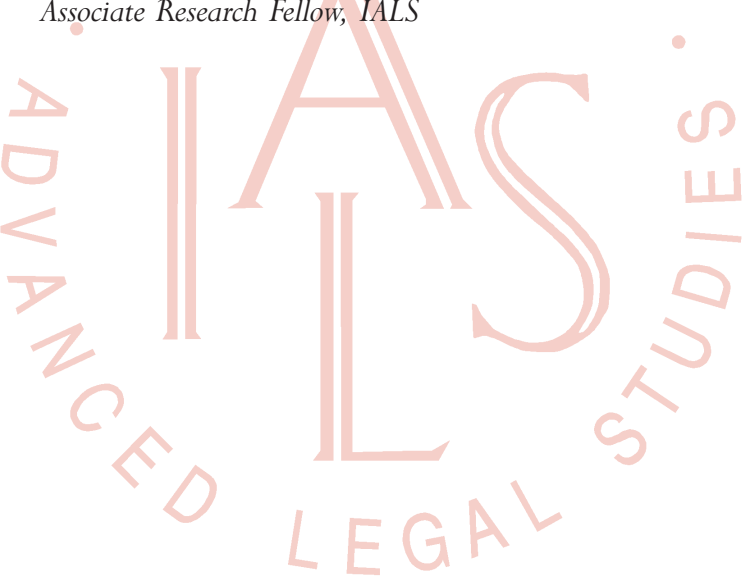

